\title{
DISINFECTION OF SECONDARY TREATED WASTEWATER USING UNDER PRESSURE DISSOLVED OXYGEN, COPPER IONS AND HYDROGEN PEROXIDE
}

\author{
R. NABIZADEH ${ }^{1}$ \\ M. ALIMOHAMMADI ${ }^{1}$ \\ R. NEMATI ${ }^{1,2}$ * \\ K. NADDAFI ${ }^{1}$ \\ S. NASERI ${ }^{1}$ \\ H. ASLANI ${ }^{1}$ \\ S.N. MOUSAVIPOUR ${ }^{1}$
}

\author{
${ }^{1}$ Department of Environmental Health Engineering \\ School of Public Health, Tehran University of Medical Sciences \\ Tehran University of Medical Sciences, Tehran, Iran \\ ${ }^{2}$ Current affiliation: Department of Environmental Health Engineering \\ School of Public Health and Paramedical \\ Semnan University of Medical Sciences \\ Aradan, Semnan, Iran
}

*to whom all correspondence should be addressed:

Accepted: $30 / 05 / 12$ e-mail: reza-nemati@hotmail.com

\section{ABSTRACT}

Many studies have been conducted to increase the efficiency of hydrogen peroxide (HP) in wastewater disinfection to make HP disinfection more cost-effective with respect to reduced concentration and detention time. In this study, the effects of HP, copper ions $\left(\mathrm{Cu}^{2+}\right)$, and $1 \mathrm{~atm}$. pressure-dissolved oxygen (termed $\mathrm{O}_{2}$ in this study) applied either alone or in a binary or ternary combination to undisinfected secondary treated wastewater (STW) were assessed.

Undisinfected STW in contact $(1 \mathrm{~h})$ with various doses of HP (alone), $\mathrm{Cu}^{2+}$ (alone), $\mathrm{HP} / \mathrm{Cu}^{2+}$ (binary) and $\mathrm{HP} / \mathrm{Cu}^{2+}$ with $\mathrm{O}_{2}$ (ternary) showed a variable fecal coliforms (FC) removal pattern, ranging from 0.03 to 3.8 logs inactivation. $\mathrm{O}_{2}$ had the highest synergistic effect when combined with $\mathrm{Cu}^{2+}$ and $\mathrm{HP}$. The use of $200 \mathrm{mg} \mathrm{L}^{-1} \mathrm{HP}+5 \mathrm{mg} \mathrm{L}^{-1} \mathrm{Cu}^{2+}$ together with $\mathrm{O}_{2}$ caused a $0.65 \mathrm{log}$ inactivation of FC more than the binary combination (i.e., $200 \mathrm{mg} \mathrm{L}^{-1} \mathrm{HP}+5 \mathrm{mg} \mathrm{L}^{-1} \mathrm{Cu}^{2+}$ ).

KEYWORDS: Fecal coliforms, Synergistic effect, Wastewater reuse.

\section{INTRODUCTION}

Secondary treated wastewater (STW) before disinfection may contain pathogenic levels of microorganisms. For example, the infectious dose of Shigella spp. is 180 organisms, while levels in STW are about $10^{4}-10^{6}$ organisms per $100 \mathrm{~mL}$ (EPA 2002; U.S. EPA 1992).

Therefore, it is essential that STW is disinfected before it is discharged or reused.

Because of a worldwide water shortage, the reuse of wastewater for various non- potable purposes including agriculture has significantly increased. Related organizations in various countries set different effluent quality guidelines and standards (Andreadakis et al., 2003). According to World Health Organization (WHO) guidelines, fecal coliforms (FC) level, which is one of the environment water quality standards, for unrestricted irrigation water should be less than 1000 organisms $/ 100 \mathrm{~mL}$ (Blumenthal et al., 2000). FC levels in raw wastewater are about $10^{6}-10^{8}$ organisms per $100 \mathrm{~mL}$, and conventional treatments without a disinfection step can reduce these levels by one to three orders of magnitude. However, due to the high initial concentration, this reduction is still inadequate, and effective disinfection is required (George et al., 2002).

Chemical disinfection is considered to be one of the most popular methods for disinfecting STW. Conventional chemical disinfectants such as chlorine gas and hypochlorite have some advantages including rapid oxidation rates, low cost and high biocide potency. However, the mutagenic and carcinogenic by-products produced due to the application of these disinfectants have motivated scientists to seek alternative methods which may be more environmentally friendly (Liberti et al., 2000; Selvakumar et al., 2009). 
Although ozone and ultraviolet light do not generate harmful by-products, high capital and operational costs are considered to be limiting factors (Drogui et al., 2000). In addition, other disinfection methods such as TiO2 photocatalysis (Melemeni et al., 2009) are novel and further full scale studies are needed to prove their cost-effectiveness.

Another alternative disinfectant is hydrogen peroxide (HP) which has a low capital cost. However, to achieve a satisfactory level of STW disinfection, high concentrations of HP and a long detention time are required (Ragab-Depre, 1982; Selvakumar et al., 2009; Wagner et al., 2002). Wagner et al. (2002) showed that to achieve a 5 log reduction of $E$. coli in STW, more than $700 \mathrm{mg} \mathrm{L}^{-1}$ of HP is required for $2 \mathrm{~h}$. Velasquez et al. (2008) reduced FC and pathogenic bacteria of advanced primary treatment effluent to acceptable levels according to international legislation, however, this required more than $250 \mathrm{mg} \mathrm{L}^{-1}$ of HP and contact times of over $2 \mathrm{~h}$.

Many studies have been conducted to increase the disinfection efficiency of HP in order to make HP disinfection more cost-effective with regard to reduced concentration and detention time (Orta De Velasquez et al., 2008; Ragab-Depre, 1982; Wagner et al., 2002). Studies have indicated that the addition of various transition metal ions to HP (Fenton reagents) can enhance the biocide activity of HP. In the Fenton reaction, reduced metal ions react with HP and produce hydroxyl radicals $(\mathrm{OH})$. Hydroxyl radicals are highly reactive and are responsible for biological damage to microbial cells (Cross et al., 2003; Ragab-Depre, 1982; Selvakumar et al., 2009; Shapiro et al., 2004). Further studies on this phenomenon showed that modification of the Fenton reagent by $\mathrm{Cu}^{2+}$, aqueous dissolved oxygen and ascorbic acid formulation have biocide potency and can destroy spores of Bacillus which are unaffected by environmental stresses such as heat radiation and toxic chemicals (Cross et al., 2003; Shapiro et al., 2004). Cross et al investigated the potency of the combination of dissolved oxygen, $\mathrm{Cu}^{2+}$ and ascorbic acid on the inactivation of Bacillus spores. They reported that dissolved oxygen increased the inactivation rate. They proposed that the simultaneous presence of $\mathrm{Cu}^{2+}$, ascorbic acid and dissolved oxygen led to the formation of hydroxyl radicals which, as noted, are responsible for cell damage (Cross et al., 2003).

In some studies, it was observed that dissolved oxygen had no effect on HP or $\mathrm{Cu}^{2+}$ biocidal potency, however, these studies did not involve the STW disinfection process (Samuni et al., 1983). In addition, it was not determined whether under pressure dissolved oxygen had the same effect or had a synergistic effect on $\mathrm{Cu}^{2+}$ and/or HP disinfection efficiency.

In this study, the effects of under pressure (1 atm) dissolved oxygen (termed $\mathrm{O}_{2}$ in this study) on STW disinfection together with HP and/or $\mathrm{Cu}^{2+}$ were studied.

\section{MATERIALS AND METHODS}

\subsection{Sampling}

Undisinfected samples were taken from a secondary sedimentation tank (before chlorination) at the Zargandeh wastewater treatment plant north east of Tehran, Iran. This wastewater treatment plant purifies municipal wastewater by a contact stabilization- extended aeration activated sludge process. The plant is designed to treat average flow of 190 cubic meter per hour which covers a polulatin of 12000 people. Samples were collected in non-reactive precleaned $10 \mathrm{I}$ containers and transported to the laboratory. All samples were examined within $5 \mathrm{~h}$.

\subsection{Materials}

Copper (II) chloride dihydrate (Merck product number 102733) was used as the $\mathrm{Cu}^{2+}$ source. All other chemicals including hydrogen peroxide $(30 \% \mathrm{w} / \mathrm{w})$ (product number 1085972500), EDTA disodium salt (product number 324503), sodium thiosulfate pentahydrate (product number 106513), A-1 medium (product number 1004150500) and sodium chloride (product number 1064041000) were purchased from Merck Chemical Company (Germany). A standard oxygen cylinder of $244 \mathrm{ft}^{3}$ at $2200 \mathrm{psi}$ and $70^{\circ} \mathrm{F}\left(6.5 \mathrm{~m}^{3}\right.$ at $15200 \mathrm{kPa}$ at $\left.20^{\circ} \mathrm{C}\right)$ was used and $\mathrm{O}_{2}$ of $99.9 \%$ purity was used as the oxygen source. In all stock solutions and other water preparations double distilled water was used. The exact concentration of HP was determined by the permanganate titration method (Huckaba and Keyes, 1948).

\subsection{Pilot set up}

Two steel containers (reactors) were set up to determine the effect of under pressure dissolved oxygen on HP and $\mathrm{Cu}^{2+}$ biocide activity. Both containers were cylindrical and were made of 
stainless steel and had a volume of $6 \mathrm{I}$. One of the containers did not have any appurtenance and was used for the disinfection experiments where $\mathrm{O}_{2}$ injection was not performed. The other container did have appurtenance which is shown schematically in Figure 1. This container was connected to a cylinder which was filled with pure oxygen $(99.9 \%$ pure) by a plastic pipe.

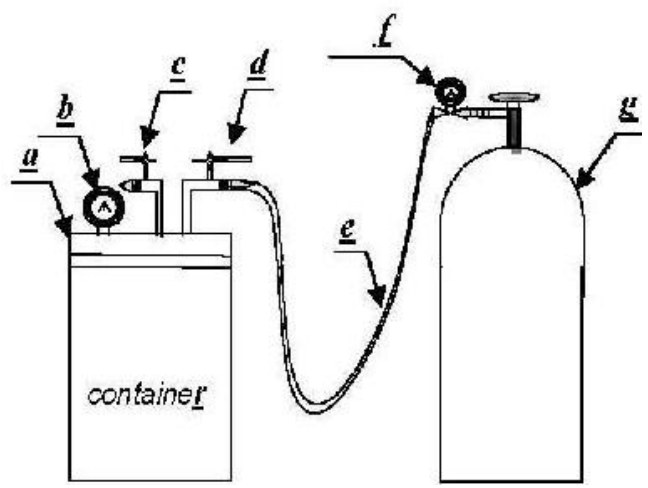

Figure 1. Schematic representation of the under pressure container. (a) Screw cap, (b) Pressure gauge, (c) Ball valve for gas pressure regulation, (d) Ball valve for oxygen gas entrance, (e) Connector hose, (f) Pressure reducing Valve, (g) Oxygen cylinder

After the addition of $1 \mathrm{l}$ of undisinfected STW to both containers and the application of appropriate doses of HP and/or $\mathrm{Cu}^{2+}$ ions to the containers, the containers were sealed immediately by closing the screw cap. The oxygen gas entrance valve (marked $d$ in Figure 1) was then opened until the pressure gauge displayed $1 \mathrm{~atm}$. pressure. An increase in pressure to more than $1 \mathrm{~atm}$. was adjusted manually by opening the gas pressure regulator valve (c in Figure 1).

\subsection{Experiments}

Parameters such as $\mathrm{TSS}, \mathrm{BOD}_{5}, \mathrm{COD}, \mathrm{pH}$, and $\mathrm{FC}$ values were tested after mixing the samples. STW characteristics (average) are presented in Table 1.

As in the pilot set up, $1 \mathrm{~L}$ of the well-mixed effluent was placed in each of the two sterile steel containers. Specified amounts of $\mathrm{HP}, \mathrm{Cu}^{2+}$ and the combined $\mathrm{HP} / \mathrm{Cu}^{2+}$ solutions were added to each container (Table 2). Contact time in all disinfection experiments was $1 \mathrm{~h}$ and started immediately after adjusting the pressure of oxygen to $1 \mathrm{~atm}$. In all experiments the sample volume was $1 \mathrm{~L}$.

As FC are a reliable indicator of microbial contamination in aquatic environments, these were selected as disinfection indicator microorganisms in this study (Niemi and Niemi, 1991).

Table 1. Physicochemical and microbiological characteristics of undisinfected STW

\begin{tabular}{|c|c|c|c|c|}
\hline \multirow{2}{*}{ Parameter } & \multicolumn{2}{|l|}{ Range } & \multirow{2}{*}{ Mean } & \multirow{2}{*}{$\begin{array}{l}\text { Standard } \\
\text { Deviation }\end{array}$} \\
\hline & Minimum & Maximum & & \\
\hline Temperature & 17.4 & 18.2 & 17.88 & 0.32 \\
\hline $\mathrm{pH}$ & 6.87 & 7.81 & 7.476 & 0.40 \\
\hline BOD5 (mg L $\left.{ }^{-1}\right)$ & 4.56 & 39.3 & 18.492 & 14.20 \\
\hline $\operatorname{COD}\left(\mathrm{mg} \mathrm{L}^{-1}\right)^{\prime}$ & 6.4 & 86.4 & 36.12 & 148 \\
\hline $\mathrm{TS}\left(\mathrm{mg} \mathrm{L}^{-1}\right)$ & 280 & 640 & 492 & 31.94 \\
\hline $\operatorname{TDS}\left(\mathrm{mg} \mathrm{L}^{-1}\right)$ & 276 & 605 & 469.1 & 134.88 \\
\hline $\begin{array}{l}\text { Fecal coliforms } \\
\text { (MPN/100 mL) }\end{array}$ & $3.5 \times 10^{5}$ & $7.0 \times 10^{5}$ & $4.9 \times 10^{5}$ & -- \\
\hline
\end{tabular}

Fecal coliforms (FC) concentrations were determined by using the multiple-tube fermentation direct test (APHA (American Public Health Association) 2005). Quantitative measurements of FC were performed before and after disinfection. All experiments were carried out at laboratory temperature $\left(22-26^{\circ} \mathrm{C}\right)$ by adding various doses of disinfectants. After completion of the disinfection detention time, HP and $\mathrm{Cu}^{2+}$ were neutralized by a stoichiometric ratio injection of sodium thiosulfate and disodium EDTA, respectively (Samuni et al., 1983; Luna-Pabello, 2009). 
Table 2. Applied disinfectant doses $\left(\mathrm{mg} \mathrm{L}^{-1}\right)$

\begin{tabular}{llll}
\hline \multirow{2}{*}{$\mathrm{HP}$} & \multirow{2}{*}{$\mathrm{Cu}^{2+}$} & \multicolumn{2}{l}{ combination } \\
\cline { 3 - 4 } & & $\mathrm{HP}$ & $\mathrm{Cu}^{2+}$ \\
\hline 0 & 0 & 0 & 0 (blank) \\
(blank) & (blank) & (blank) & 0.01 \\
10 & 0.01 & 10 & 0.1 \\
20 & 0.1 & 20 & 0.5 \\
50 & 0.5 & 50 & 1 \\
100 & 1 & 100 & 3 \\
150 & 3 & 150 & 5 \\
200 & 5 & 200 & - \\
300 & - & - & - \\
600 & - & - & \\
\hline
\end{tabular}

\section{RESULTS}

\section{1. $\mathrm{HP}$ and $\mathrm{HP} / \mathrm{O}_{2}$ disinfection}

The efficiencies of $\mathrm{HP}$ and $\mathrm{HP} / \mathrm{O}_{2}$ on $\mathrm{FC}$ inactivation in undisinfected STW are shown in Figure 2. It can be seen from this figure that $\mathrm{O}_{2}$ alone $\left(\mathrm{HP}=0 \mathrm{mg} \mathrm{L}^{-1}\right)$ did not eliminate a significant number of FC. Moreover, neither increasing the HP dose up to $50 \mathrm{mg} \mathrm{L}^{-1}$ alone or the combination of HP and $\mathrm{O}_{2}$ (i.e., $\mathrm{HP} / \mathrm{O}_{2}$ ) had a significant effect on $\mathrm{FC}$ levels. Considerable $\mathrm{FC}$ inactivation occurred at $\mathrm{HP}$ doses higher than $50 \mathrm{mg} \mathrm{L}^{-1}$. With increasing HP concentration up to $200 \mathrm{mg} \mathrm{L}^{-1}$, the FC inactivation efficiencies of both $\mathrm{HP}$ and $\mathrm{HP} / \mathrm{O}_{2}$ increased sharply. In the range of $50-200 \mathrm{mg} \mathrm{L}^{-1}$, $\mathrm{FC}$ log inactivation by $\mathrm{HP}$ and $\mathrm{HP} / \mathrm{O}_{2}$ increased from 0.03 and 0.1 logs at $50 \mathrm{mg} \mathrm{L}^{-1} \mathrm{HP}$ to 1.18 and 1.37 logs at $200 \mathrm{mg} \mathrm{L}^{-1}$, respectively. For HP doses higher than $200 \mathrm{mg} \mathrm{L}^{-1}$, the increase was slower; at an $\mathrm{HP}$ dose of $600 \mathrm{mg} \mathrm{L}^{-1}$, FC log inactivation by $\mathrm{HP}$ and $\mathrm{HP} / \mathrm{O}_{2}$ was 1.46 and 1.94 , respectively. However, despite the high doses of $\mathrm{HP}$, neither $\mathrm{HP}$ nor $\mathrm{HP} / \mathrm{O}_{2}$ satisfied the microbial requirements set by WHO.

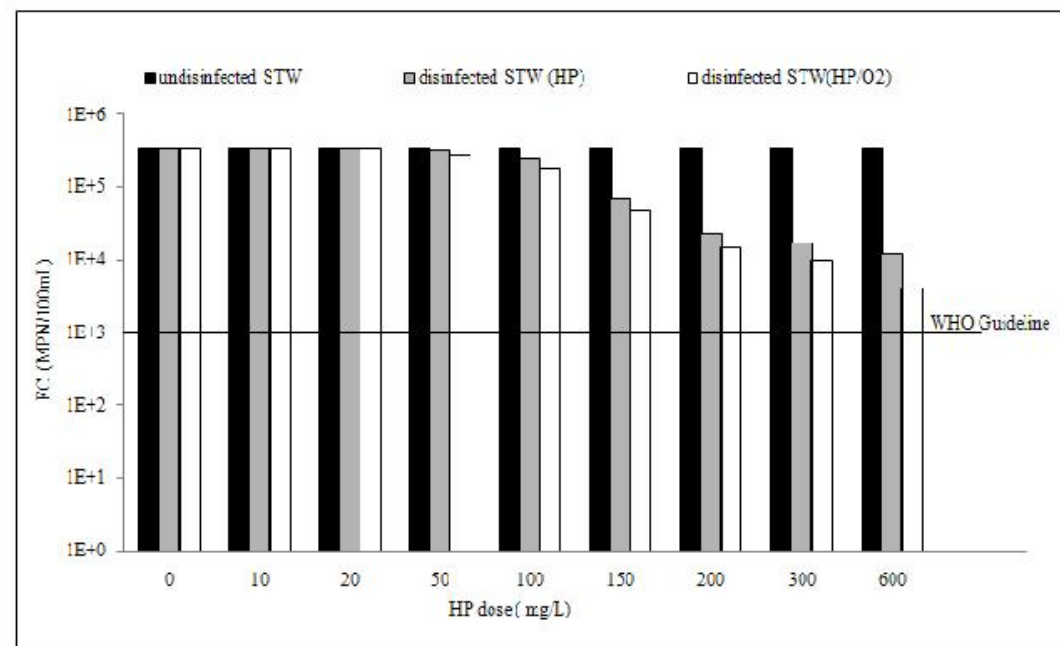

Figure 2. FC levels in STW before and after disinfection using various doses of $\mathrm{HP}$ alone and together with $\mathrm{O}_{2}$ (contact time $=1 \mathrm{~h}$ )

The synergistic effect of $\mathrm{O}_{2}$ on HP disinfection is shown in Figure 3a. The synergistic effect was obtained by subtracting the log inactivation value of an individual disinfection agent from the log inactivation value of their combination. It can be seen that the $\mathrm{O}_{2}$ synergistic effect at low doses of HP had a significant role in disinfection efficiency and its quantities gradually increased. In contrast, its role at moderate doses varied slightly and with increasing HP dose its proportional share decreased. Although at the highest doses this value increased. 


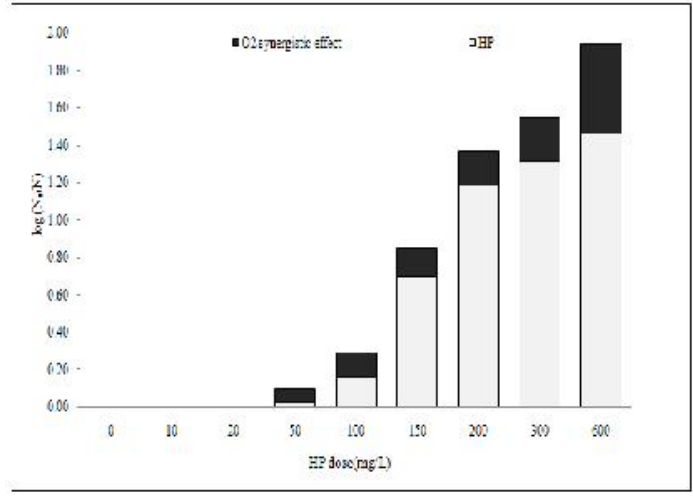

(a)

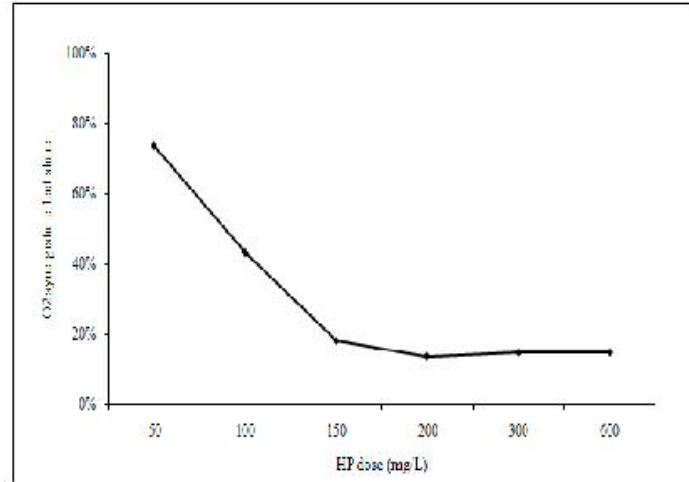

(b)

Figure 3. Proportional share of HP and synergistic effect of $\mathrm{O}_{2}$ in $\mathrm{FC}$ inactivation using various doses of HP together with $\mathrm{O}_{2}\left(\right.$ a) and $\mathrm{O}_{2}$ synergism effect share variations in STW disinfection using various doses of HP together with $\mathrm{O}_{2}(b)$

When the total disinfection efficiency of $\mathrm{HP} \mathrm{O}_{2}$ was considered, the proportional share of the $\mathrm{O}_{2}$ synergistic effect was still low. From Figure $3 a$ it can be seen that the proportional share of the $\mathrm{O}_{2}$ synergic effect on HP disinfection efficiency ranged from 0.07 logs at an HP dose of $50 \mathrm{mg} \mathrm{L}^{-1}$ to 0.48 logs at an HP dose of $600 \mathrm{mg} \mathrm{L}^{-1}$ which was considered a low synergistic effect. Figure $3 \mathrm{~b}$ displays the proportional share of the $\mathrm{O}_{2}$ synergistic action variations on HP disinfection efficiency. It can be seen that the $\mathrm{O}_{2}$ proportional share was significantly decreased from around $74 \%$ at an $\mathrm{HP}$ dose of $50 \mathrm{mg} \mathrm{L}^{-1}$ to $18 \%$ at $150 \mathrm{mg} \mathrm{L}^{-1} \mathrm{HP}+\mathrm{O}_{2}$. At higher doses, this value continued to decrease, but its slope was very slow and at higher doses it was almost constant. The value at the highest dose (i.e. $600 \mathrm{mg} \mathrm{L}^{-1} \mathrm{HP}$ ) was about $15 \%$.

\section{2. $\mathrm{Cu}^{2+}$ and $\mathrm{Cu}^{2+} / \mathrm{O}_{2}$ disinfection}

As illustrated in Figure 4, disinfection of secondary effluent with $\mathrm{Cu}^{2+}$ or $\mathrm{Cu}^{2+} / \mathrm{O}_{2}$ reduced $\mathrm{FC}$. The disinfecting effect of $\mathrm{Cu}^{2+}$ and $\mathrm{Cu}^{2+} / \mathrm{O}_{2}$ was observed at doses higher than $0.1 \mathrm{mg} \mathrm{L}^{-1}$. As an overall trend, it is clear that increasing concentrations of $\mathrm{Cu}^{2+}$ caused a corresponding increase in the $\mathrm{FC}$ inactivation rate due to $\mathrm{Cu}^{2+}$ and $\mathrm{Cu}^{2+} / \mathrm{O}_{2}$.

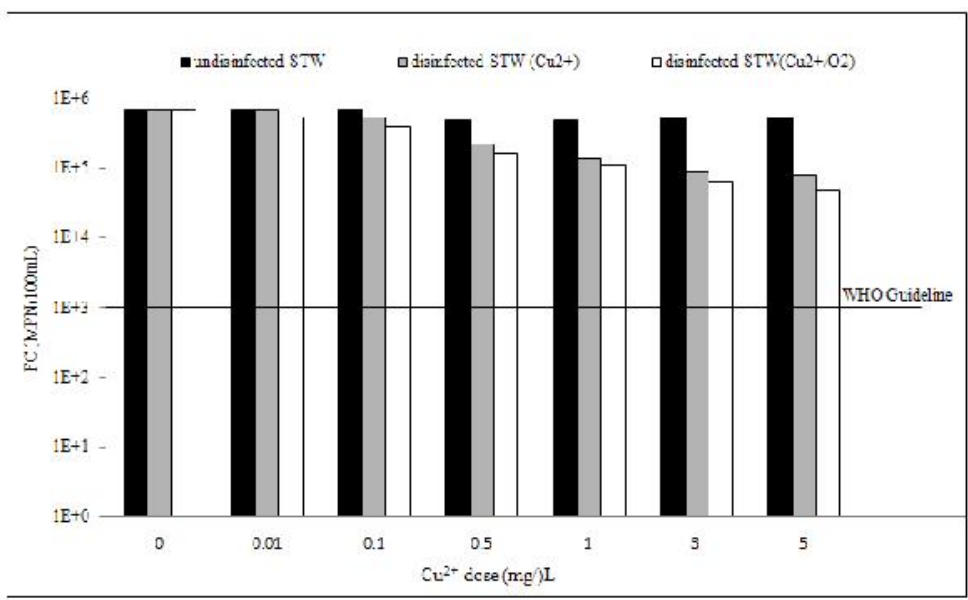

Figure 4. FC levels in STW before and after disinfection using various doses of $\mathrm{Cu}^{2+}$ alone and together with $\mathrm{O}_{2}$ (contact time $\left.=1 \mathrm{~h}\right)$

Death rates of $\mathrm{FC}$ increased gradually up to $1 \mathrm{mg} \mathrm{L}^{-1} \mathrm{Cu}^{2+}$ and continued to increase slowly at higher doses. The application of $\mathrm{Cu}^{2+}$ (alone) at doses of $0.1,1$, and $5 \mathrm{mg} \mathrm{L}^{-1}$ caused a $0.1,0.5$, and 0.83 log reduction, respectively; the corresponding log reductions for the $\mathrm{Cu}^{2+} / \mathrm{O}_{2}$ combination were 0.2 , 0.6 , and 1 , respectively. Therefore, the efficiency of disinfection with $\mathrm{Cu}^{2+}$ or $\mathrm{Cu}^{2+} / \mathrm{O}_{2}$ was not sufficient to meet the WHO criteria for wastewater re-use.

The relative share of the $\mathrm{O}_{2}$ synergistic action in the disinfection efficiency of $\mathrm{Cu}^{2+}$ is shown in Figure 5a. It can be seen that this value increased as the $\mathrm{Cu}^{2+}$ dose increased. Since the increased disinfection rate due to $\mathrm{Cu}^{2+}$ was significantly higher than the $\mathrm{O}_{2}$ synergistic effect increase, the $\mathrm{O}_{2}$ 
(synergistic effect) proportional share rapidly decreased. The variation in the $\mathrm{O}_{2}$ synergistic effect vs. $\mathrm{Cu}^{2+}$ doses is shown in Figure $5 \mathrm{~b}$. It can be seen that at low $\mathrm{Cu}^{2+}$ doses, the $\mathrm{O}_{2}$ synergistic effect was very important in the disinfection efficiency. This value decreased from about $100 \%$ at the lowest dose $\left(0.01 \mathrm{Cu}^{2+}\right)$ to about $20 \%$ at the highest dose. Although, the synergistic effect of $\mathrm{O}_{2}$ on the disinfection of STW with $\mathrm{Cu}^{2+}$ increased due to the application of higher doses of $\mathrm{Cu}^{+2}$, the effect (about 0.2 log reductions) was not considered practically significant.

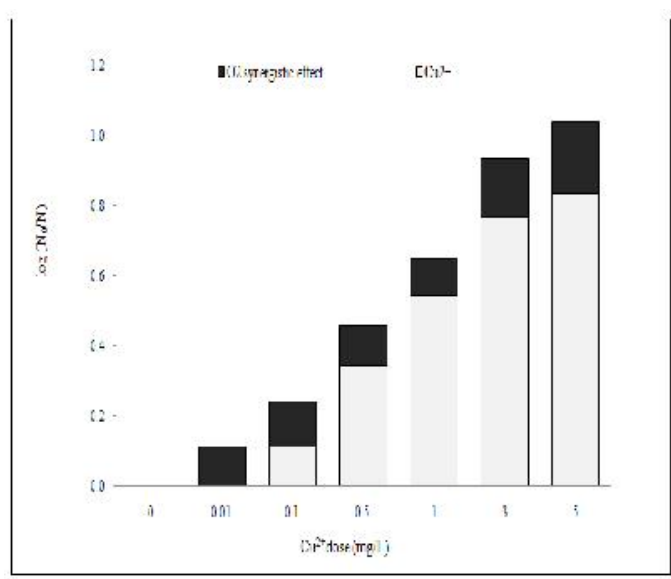

(a)

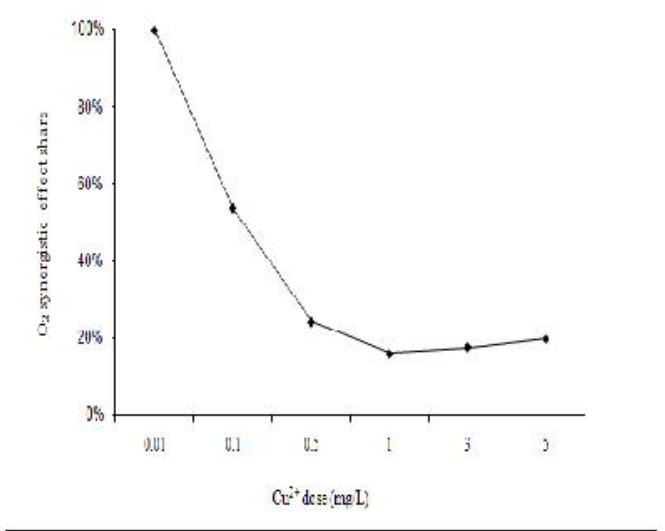

(b)

Figure 5. Proportional share of $\mathrm{Cu}^{2+}$ and the synergistic effect of $\mathrm{O}_{2}$ on $\mathrm{FC}$ inactivation using various doses of $\mathrm{Cu}^{2+}$ together with $\mathrm{O}_{2}(\mathrm{a})$ and the $\mathrm{O}_{2}$ synergism effect share variations on STW disinfection using various doses of $\mathrm{Cu}^{2+}$ together with $\mathrm{O}_{2}(\mathrm{~b})$

\section{3. $\mathrm{Cu}^{2+} / \mathrm{HP}$ and $\mathrm{Cu}^{2+} / \mathrm{HP} / \mathrm{O}_{2}$ disinfection}

The effects of the binary combination of $\mathrm{HP} / \mathrm{Cu}^{2+}$ and the ternary combination of $\mathrm{HP} / \mathrm{Cu}^{2+} / \mathrm{O}_{2}$ on $\mathrm{FC}$ levels in undisinfected STW are presented in Figure 6. It can be seen that the FC inactivation rate in the binary (i.e., $\mathrm{Cu}^{2+} / \mathrm{HP}$ ) and ternary (i.e., $\mathrm{Cu}^{2+} / \mathrm{HP}^{-\mathrm{O}_{2}}$ ) combinations rapidly increased as $\mathrm{Cu}^{2+}$ and $\mathrm{HP}$ increased. As illustrated in Figure 6 , the combination of $\mathrm{Cu}^{2+} / \mathrm{HP}$ at the highest dose (i.e., 200 $\mathrm{mg} \mathrm{L}^{-1} \mathrm{HP}+5 \mathrm{mg} \mathrm{L}^{-1} \mathrm{Cu}^{2+}$ ) led to a significant drop in FC level to $450 \mathrm{MPN} / 100 \mathrm{~mL}$ complying with the WHO effluent standard (FC $1000 \mathrm{MPN} / 100 \mathrm{~mL}$ ). The addition of $\mathrm{O}_{2}$ to the $\mathrm{HP} / \mathrm{Cu}^{2+}$ combinations catalyzed the $\mathrm{FC}$ inactivation rate so that this combination was capable of achieving the WHO standard level at a lower dose $\left(150 \mathrm{mg} \mathrm{L}^{-1} \mathrm{HP}+3 \mathrm{mg} \mathrm{L}^{-1} \mathrm{Cu}^{2+}+\mathrm{O}_{2}\right)$. The ternary combination at the highest applied dose $\left(200 \mathrm{mg} \mathrm{L}^{-1} \mathrm{HP}+5 \mathrm{mg} \mathrm{L}^{-1} \mathrm{Cu}^{2+}+\mathrm{O}_{2}\right)$ in this study decreased FC concentration to $100 \mathrm{MPN} / 100 \mathrm{~mL}$ and when the initial FC concentration was considered, this was equivalent to a $3.7 \mathrm{log}$ reduction. A comparison of the binary and ternary disinfection efficiency revealed that $\mathrm{O}_{2}$ had a significant synergistic effect on $\mathrm{HP} / \mathrm{Cu}^{2+}$ disinfection.

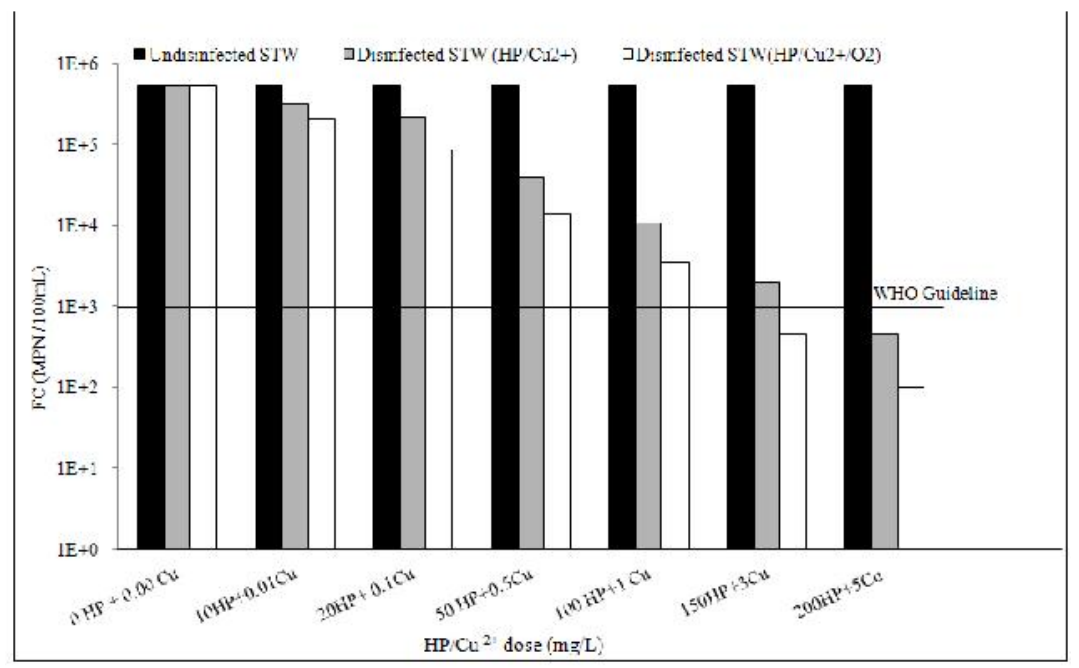

Figure 6. FC levels in STW before and after disinfection using various doses of $\mathrm{HP}$ alone and together with $\mathrm{O}_{2}$ (contact time $=1 \mathrm{~h}$ ) 
The synergistic influence of $\mathrm{Cu}^{2+}$ on HP is shown in Figure 7a. It can be seen that at lower doses, synergism plays the main role in FC inactivation. In addition, this figure shows that the synergistic effect of $\mathrm{Cu}^{2+}$ at lower doses was considerably increased, but at higher doses the value remained almost constant. The synergistic share of the lowest applied dose $\left(10 \mathrm{mg} \mathrm{L}^{-1} \mathrm{HP}+0.01 \mathrm{mg} \mathrm{L}^{-1} \mathrm{Cu}^{2+}\right)$ was $0.21 \mathrm{log}$. When the combinations of $100 \mathrm{mg} \mathrm{L}^{-1} \mathrm{HP}+1 \mathrm{mg} \mathrm{L}^{-1} \mathrm{Cu}^{2+}$ and $200 \mathrm{mg} \mathrm{L}^{-1} \mathrm{HP}+5 \mathrm{Cu}^{2+}$ $\mathrm{mg} \mathrm{L}^{-1}$ were used this value was enhanced to $0.96 \mathrm{log}$ and $1.06 \mathrm{log}$, respectively. Figure $7 \mathrm{~b}$ demonstrates the portion of the $\mathrm{Cu}^{2+}$ synergistic effect in the disinfection process. It can be seen that with increasing doses this portion quickly declined. At the lowest employed dose (i.e. $10 \mathrm{mg} \mathrm{L}^{-1} \mathrm{HP}+$ $0.01 \mathrm{mg} \mathrm{L}^{-1} \mathrm{Cu}^{2+}$ ) nearly all of the disinfection efficiency was related to synergistic action, however, this value at the highest employed dose $\left(200 \mathrm{mg} \mathrm{L}^{-1} \mathrm{HP}+5 \mathrm{mg} \mathrm{L}^{-1} \mathrm{Cu}^{2+}\right)$ reduced to about $34 \%$.

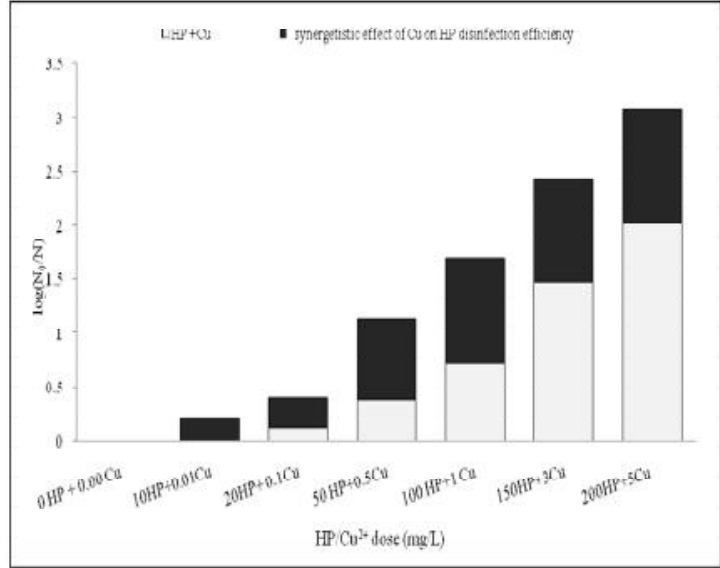

(a)

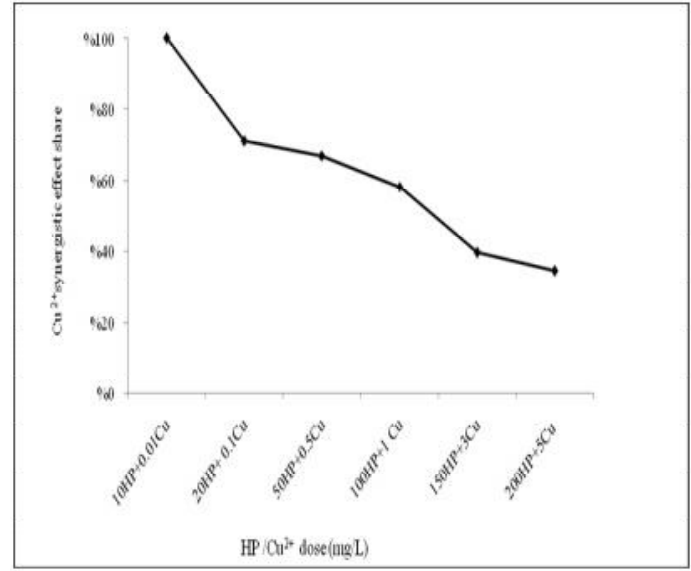

(b)

Figure 7. Proportional share of $\mathrm{HP}+\mathrm{Cu}^{2+}$ and the synergistic effect of $\mathrm{Cu}^{2+}$ on $\mathrm{FC}$ inactivation using various doses of $\mathrm{HP} / \mathrm{Cu}^{2+}(a)$ and the $\mathrm{Cu}^{2+}$ synergism effect share variations on STW disinfection using various doses of $\mathrm{HP}$ and $\mathrm{Cu}^{2+}$ combinations (b)

Figure 8a shows the $\mathrm{O}_{2}$ synergistic effect on $\mathrm{HP} / \mathrm{Cu}^{2+}$ disinfection efficiency. At lower doses the synergistic effect of $\mathrm{O}_{2}$ gradually increased, but at higher doses this effect remained stable. This value increased from 0.2 log inactivation at $10 \mathrm{mg} \mathrm{L}^{-1} \mathrm{HP}+0.1 \mathrm{mg} \mathrm{L}^{-1} \mathrm{Cu}^{2+}$ combination to 0.5 and $0.65 \mathrm{log}$ inactivation at $100 \mathrm{mg} \mathrm{L}^{-1} \mathrm{HP}+1 \mathrm{mg} \mathrm{L}^{-1} \mathrm{Cu}^{2+}$ and $200 \mathrm{mg} \mathrm{L}^{-1} \mathrm{HP}+5 \mathrm{mg} \mathrm{L}^{-1} \mathrm{Cu}^{2+}$ combinations, respectively. Figure $8 \mathrm{~b}$ demonstrates the proportional share of the $\mathrm{O}_{2}$ synergistic action in the ternary combination $\left(\mathrm{HP} / \mathrm{Cu}^{2+} / \mathrm{O}_{2}\right)$. It is obvious that the synergistic share of $\mathrm{O}_{2}$ at lower doses was higher and at the lowest applied dose it was about $50 \%$. This value decreased sharply to $29 \%$ at the $50 \mathrm{mg} \mathrm{L}^{-1} \mathrm{HP}+0.5 \mathrm{mg} \mathrm{L}^{-1} \mathrm{Cu}^{2+}$ combination and continued to decrease but with a gentle slope to around $20 \%$ at the highest dose $\left(200 \mathrm{mg} \mathrm{L}^{-1} \mathrm{HP}+5 \mathrm{mg} \mathrm{L}^{-1} \mathrm{Cu}^{2+}\right)$.

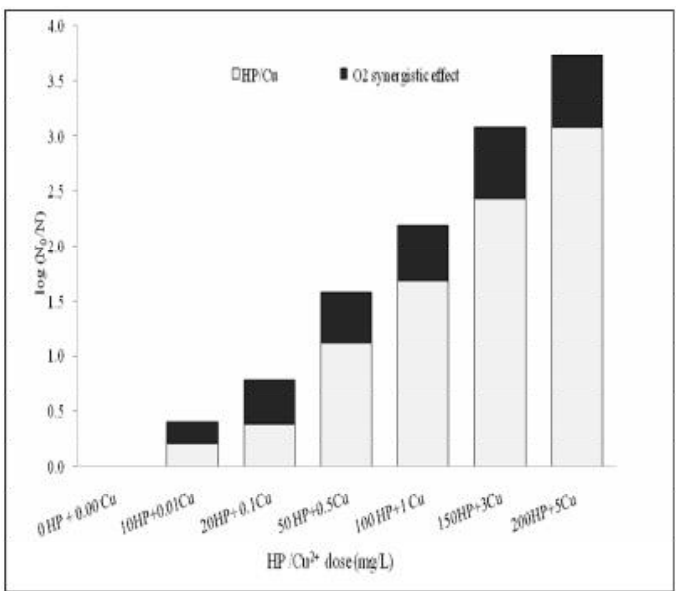

(a)

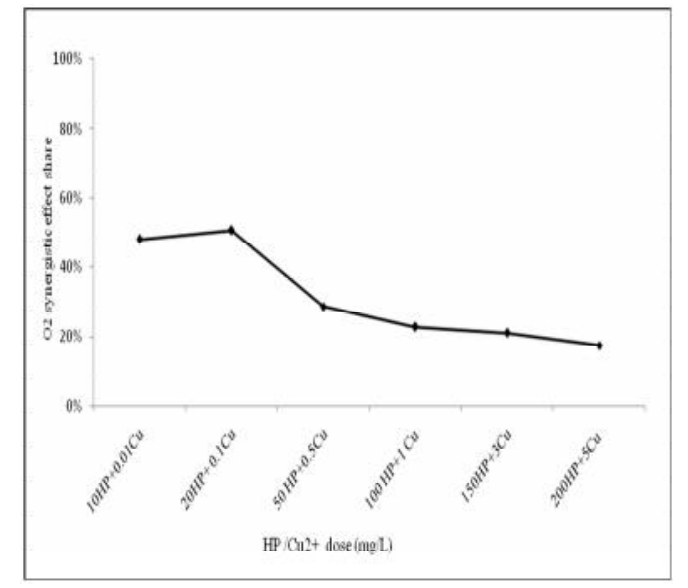

(b)

Figure 8. Proportional share of $\mathrm{HP} / \mathrm{Cu}^{2+}$ and the synergistic effect of $\mathrm{O}_{2}$ on $\mathrm{FC}$ inactivation using various doses of $\mathrm{HP} / \mathrm{Cu}^{2+}$ together with $\mathrm{O}_{2}(\mathrm{a})$ and the $\mathrm{O}_{2}$ synergistic effect share variations on STW disinfection using various doses of HP together with $\mathrm{O}_{2}(\mathrm{~b})$ 


\section{DISCUSSION}

Similar to many previous studies (Orta De Velasquez, 2008; Wagner et al., 2002), the application of HP (alone) on STW disinfection in our study was unsuccessful. The application of $600 \mathrm{mg} \mathrm{L}^{-1}$ with a contact time of I h $\left(\mathrm{C} . \mathrm{T}=36000 \mathrm{mg} \cdot \mathrm{min}^{-1}\right)$ was not effective in reducing the $\mathrm{FC}$ level below the WHO standard level for agricultural use ( $\leq 1000 \mathrm{MPN} / 100 \mathrm{~mL}$ ). Velasquez et al. (Orta De Velasquez, 2008) reported that to achieve acceptable $\mathrm{FC}$ and pathogenic levels in advanced primary treatment effluents using HP, the required dose should be more than $250 \mathrm{mg} \mathrm{L}^{-1}$; and the contact time should be longer than 120 minutes (C.T>30000).

Although adding $\mathrm{Cu}^{2+}$ to HP can increase the disinfection efficiency, it should be noted that $\mathrm{Cu}$ is a bioaccumulative environmental toxin, which can disrupt the balance of soil and aquatic life (LunaPabello et al., 2009).

Agricultural-based guideline values for $\mathrm{Cu}$ in irrigation water are variable. For example, the Iranian Environmental Protection Organization (Iran EPO, 1995), the U.S. Environmental Protection Agency (EPA), (EPA 2004), the Australian/New Zealand Environment Conservation Council (ANZECC), (ANZECC, 2000) and the Food and Agriculture Organization of the United Nations (FAO), (FAO 1992) set an effluent limit of $0.2 \mathrm{mg} \mathrm{L}^{-1}$ for $\mathrm{Cu}^{2+}$, while this limit in Saudi Arabia and Oman is 0.4 and $1 \mathrm{mg} \mathrm{L}^{-1}$, respectively (CEHA, 2006).

In some guidelines for irrigation water quality, the limitations of effluent components are set according to the duration of effluent loading. These guidelines introduced the long-term use value (the maximum concentration of contaminant in the irrigation water which can be tolerated assuming 100 years) and the short-term use value (maximum concentration of contaminant in the irrigation water which can be tolerated for a shorter time period of 20 years) (ANZECC, 2000). According to U.S. EPA and ANZECC guidelines for irrigation water quality, the maximum allowable concentration of $\mathrm{Cu}$ in irrigation water for long-term use and short-term use is 0.2 and $5 \mathrm{mg} \mathrm{L}^{-1}$, respectively (ANZECC, 2000; EPA, 2004). Therefore, using binary combinations of $\mathrm{HP} \mathrm{Cu}^{2+}$ and ternary combinations of $\mathrm{HP} / \mathrm{Cu}^{2+} / \mathrm{O}_{2}$ (containing less than $5 \mathrm{mg} \mathrm{L}^{-1} \mathrm{Cu}^{2+}$ ) for STW disinfection are acceptable for short-term use. For long-term application, effluent dilution with other water sources seems to be the only way of meeting the standard value which is not practically feasible in many cases, especially where disinfected effluents are the only sources for irrigation.

It should be noted that some reputed organizations such as WHO did not set limitations for $\mathrm{Cu}^{2+}$ and other metals in treated effluents used for irrigation. However, WHO and other agencies are more focused on monitoring these constituents in soil rather than setting rigid limitations for $\mathrm{Cu}^{2+}$ and other metals in effluent. As previously mentioned $\mathrm{Cu}$ reacts with organic matter in effluents (e.g. proteins) and is converted to highly stable compounds which have lower toxicity (Luna-Pabello 2009).

As observed, $\mathrm{O}_{2}$ had a synergistic effect on disinfection with $\mathrm{HP}, \mathrm{Cu}^{2+}$ and the combination of $\mathrm{HP} / \mathrm{Cu}^{2+}$. Since the $\mathrm{O}_{2}$ synergistic effect on HP or $\mathrm{Cu}^{+}$was not enough to meet the microbial quality requirements in conventional doses, it seems that using $\mathrm{HP}$ or $\mathrm{Cu}^{2+}$ together with $\mathrm{O}_{2}$ is not applicable. As seen in Figure 6, the binary combination of $\mathrm{HP} / \mathrm{Cu}^{2+}$ at the highest dose (i.e. $200 \mathrm{mg}$ $\mathrm{L}^{-1} \mathrm{HP}+5 \mathrm{mg} \mathrm{L}^{-1} \mathrm{Cu}^{2+}$ ) and the ternary combination at the two highest doses caused $\mathrm{FC}$ levels to drop below the WHO guideline level for unrestricted irrigation.

Khazaie M. et al. (2007) studied the efficiency of hydrogen peroxide-silver ion complex in removing total coli forms from samples taken from Qom wastewater. In the concentration of 80 and $480 \mathrm{mg} \mathrm{L}^{-}$ ${ }_{1}^{1}$, logarithmic removal value of total coli forms was 1.9 and 4.5 respectively. In CT value $8600 \mathrm{mg} \mathrm{L}^{-}$ ${ }^{1}$.min and more, the total coli forms effluent standard for surface water discharge and agriculture irrigation was achieved. It was concluded that the use of hydrogen peroxide-silver ion complex as a water and wastewater disinfectant, has some benefits such as elimination of hazardous by products, and measurable residual amount. However its application in wastewater effluent is more costly than other usual disinfectants so it is not economically advisable (Khazaie et al., 2007). It is remarkable that ternary combinations at lower doses of $\mathrm{HP} / \mathrm{Cu}^{2+}$ (i.e., at $150 \mathrm{mg} \mathrm{L}^{-1} \mathrm{HP}+3 \mathrm{mg} \mathrm{L}^{-1} \mathrm{Cu}^{2+}$ ) rather than the binary combination of $\mathrm{HP} / \mathrm{Cu}^{2+}$ (i.e., at $200 \mathrm{mg} \mathrm{L}^{-1}+5 \mathrm{mg} \mathrm{L}^{-1} \mathrm{Cu}^{2+}$ ) meet the WHO guideline FC levels for unrestricted irrigation. Dissolved Air Flotation (DAF), the process of removing suspended solids, oils and other contaminants via the use of air bubble, was extensively used in the field of wastewater treatment. Application of under pressure dissolved oxygen in disinfection would be simpler and technically practical. Oxygen is dissolved into wastestream (in a pressure vessel tank) which comes from the secondary sedimentation tank of a activated sludge system and is 
released from solution at the end of contact time. The higher microbial effectiveness and better effluent quality may be compensating factors for the high $\mathrm{O}_{2}$ costs.

\section{CONCLUSION}

Our study showed that $\mathrm{O}_{2}$ has a noticeable synergistic effect on the disinfection efficiency of HP, $\mathrm{Cu}^{2+}$ and the combination of $\mathrm{HP} / \mathrm{Cu}^{2+}$. The greatest synergistic effects were seen when the combination of $\mathrm{HP} / \mathrm{Cu}^{2+}$ was used which met the international legislation on microbial quality for STW. Previous research revealed that for achieving a satisfactory level of STW disinfection, high concentrations of HP and a long detention time are required (Ragab-Depre, 1982; Selvakumar et al., 2009; Wagner et al., 2002). Wagner et al. (2002) showed that to achieve a 5 log reduction of $E$. coli in STW, more than $700 \mathrm{mg} \mathrm{L}^{-1}$ of HP is required for $2 \mathrm{~h}$. We could reduce the amount of required hydrogen peroxide using hydrogen peroxide-silver ion complex in our previous study. In this study, it was concluded that using $200 \mathrm{mg} \mathrm{L}^{-1} \mathrm{HP}+5 \mathrm{mg} \mathrm{L}^{-1} \mathrm{Cu}^{2+}$ and under pressure dissolved oxygen caused FC levels to drop below the WHO guideline level for unrestricted irrigation. According to the objective of present study, it is concluded that using under pressure dissolved oxygen could be considered as an interventional combination process to reduce the amount of required hydrogen peroxide. But, the HP dose is still high and more research should be performed to reduce the disinfectant concentrations to an economically feasible level.

\section{ACKNOWLEDGEMENT}

This research was supported by Tehran University of Medical Sciences and Health Services grant.

\section{REFERENCES}

Andreadakis A., Gavalaki E., Mamais D. and Tzimas A. (2003). Wastewater reuse criteria in Greece, Global NEST: the Int. J., 5(1), 9-14.

ANZECC (2000). Water quality for irrigation and general use, Australian and New Zealand Environment Conservation Council (ANZECC).

APHA (American Public Health Association) AWWA (American Water Works Association), WEF (Water Environment Federation) (2005). Standard Methods for the Examination of Water and Wastewater.

Blumenthal U.J., Mara D.D., Peasey A., Ruiz-Palacios G. and Stott R. (2000). Guidelines for the microbiological quality of treated wastewater used in agriculture: recommendations for revising WHO guidelines, Bulletin of the World Health Organization, 78, 1104-1116.

CEHA (2006). A compendium of standards for wastewater reuse in the Eastern Mediterranean Region, World Health Organization Regional Office for the Eastern Mediterranean, Regional Centre for Environmental Health Activities.

Cross J.B., Currier R.P., Torraco D.J., Vanderberg L.A., Wagner G.L. and Gladen P.D. (2003). Killing of bacillus spores by aqueous dissolved oxygen, ascorbic acid, and copper ions, Appl Environ Microbiol, 69(4), 2245-52.

Drogui P., Elmaleh S., Rumeau M., C. Bernard and Rambaud A. (2000). Hydrogen peroxide production by water electrolysis: Application to disinfection, Journal of Applied Electrochemistry, 31, 887-882.

EPA (Victoria Australia) (2002). Guidelines for Environmental Management: disinfection of treated wastewater, Environmental Protection Agency (EPA), Publication 730 Victoria, Australia.

EPA U.S. (2004). Guidelines for Water Reuse, U.S. Environmental Protection Agency, EPA/625/R-04/108

FAO (1992). Wastewater treatment and use in agriculture.Pescod M.B. FAO Irrigation and Drainage Paper 47, food and agriculture organization of the united nations (FAO), Rome.

George I., Crop P. and Servais P. (2002). Fecal coliform removal in wastewater treatment plants studied by plate counts and enzymatic methods, Water Research, 36(10), 2607-2617.

Huckaba C.E. and Keyes F.G. (1948). The Accuracy of Estimation of Hydrogen Peroxide by Potassium Permanganate Titration, Journal of the American Chemical Society, 70(4), 1640-1644.

Iran EPO (1995) Guidelines for wastewater reuse in agricultural purposes, Iran environmental protection organization.

Khazaie M., Nabizadeh R., Naddafi K., Vaezi F., Yunesian M., Roshany M. and Farzinnia B. (2007). Qom Wastewater Disinfection with Hydrogen Peroxide-Silver Ion Complex, Qom University of Medical Sciences, 1(4), 31-37.

Luna-Pabello V.M., Ríos M.M., Jiménez B. and orta de Velasquez M.T. (2009). Effectiveness of the use of Ag, Cu and PAA to disinfect municipal wastewater, Environmental Technology, 30(2), 129 - 139. 
Melemeni M., Stamatakis D., Xekoukoulotakis N.P., Mantzavinos D. and Kalogerakis N. (2009). Disinfection of municipal wastewater by tio2 photocatalysis with uv-a, visible and solar irradiation and bdd electrolysis, Global Nest, 11(3), 357-363.

Niemi R.M. and Niemi J.S. (1991). Bacterial Pollution of Waters in Pristine and Agricultural Lands, $J$ Environ Qual, 20(3), 620-627.

Orta De Velasquez M.T., Yanez.Noguez I., Jimenez-Cisneros B., Luna Pabello V.M. (2008). Adding silver and copper to hydrogen peroxide and peracetic acid in the disinfection of an advanced primary treatment effluent, Environ Technol., 29(11), 1209-17.

Ragab-Depre N.J. (1982). Water disinfection with the hydrogen peroxide-ascorbic acid-copper (II) system, Appl Environ Microbiol, 44(3), 555-60.

Samuni A., Aronovitch J., Godinger G., Chevion M. and Czapski G. (1983). On the cytotoxicity of vitamin $C$ and metal ions, European Journal of Biochemistry, 137(1-2), 119-124.

Selvakumar A., Tuccillo M.E., Muthukrishnan S. and Asim R.B. (2009). Use of Fenton's Reagent as a Disinfectant, Remediation, 19(2), 135-142.

Shapiro M.P., Setlow B. and Setlow P. (2004). Killing of Bacillus subtilis spores by a modified Fenton reagent containing CuCl2 and ascorbic acid, Appl Environ Microbiol, 70(4), 2535-2539.

U.S.EPA (1992). Manual Guidelines for Water Reuse, United States Environmental Protection Authority. EPA/625/R- 92/004.

Wagner M., Brumelis D. and Gehr R. (2002). Disinfection of wastewater by hydrogen peroxide or peracetic acid: development of procedures for measurement of residual disinfectant and application to a physicochemically treated municipal effluent, Water Environ Res., 74(1), 33-50. 